\title{
6.5 Аналіз використання Lactobacillus reuteri як пробіотика
}

Щорічно зростає кількість людей, що мають різноманітні розлади шлунково-кишкового тракту. Серед порушень функціонування травної системи людини важливе місце займає дисбактеріоз, що є однією з найпоширеніших «хворіб цивілізації». Офіційно дисбактеріоз не реєструється як захворювання, однак відновленню та нормалізації мікробіоти шлунково-кишкового тракту (ШКТ) в останні роки приділяється багато уваги. Існує цілий ряд причин виникнення дисбактеріозу, зокрема нестача нуртієнтів, мінералів, вітамінів, харчових волокон, але найважливішою причиною є надмірне використання антибіотиків широкого спектру дії.

Антибіотики широкого спектру дії використовуються не тільки для лікування в екстрених ситуаціях, коли необхідно ефективно захистити організм людини від різної патогенної мікрофлори, але й як профілактично міра, що $\epsilon$ абсолютно неефективно і шкідливо для організму людини. Згідно статистичних даних, щороку у США витрачають близько 10 млрд. доларів США на антибіотики. Проте, деякі функціональні розлади здоров'я людини можна виправити за допомогою пробіотиків.

Пробіотики — це живі мікроорганізми, які можуть позитивно впливати на здоров’я людини, нормалізувати склад i функції мікрофлори шлунковокишкового тракту. Пробіотичні лікарські засоби $є$ не тільки високоефективними проти умовно-патогенних бактерій, вони забезпечують відновлення здорової мікробіоти шлунково-кишкового тракту, що дозволяє отримати швидше одужання та нормальне функціонування організму в цілому.

Найбільш ефективним передбачається використання в якості пробіотиків тих бактерії, що є автохтонними для людини, а також продукти, які їх містять, та мають потенціал застосування у промисловості. Тому найчастіше у склад різних пробіотиків входять представники роду Lactobacillus завдяки їхній фізіологічній та технологічній значимості. 
Створення харових продуктів та лікарських засобів, що мають пробіотичні властивості, є одним з найважливіших завдань, що стоїть перед біотехнологами, фармацевтами та харчовими технологами.

На основі наукових досліджень можна зробити висновок, що впровадження біологічно-активних добавок для нормалізації ШКТ та функціонування організму людини в цілому у доступній для споживача формі $\epsilon$ конкретним та перспективним завданням для розвитку галузі. Тому, у цій роботі запропоновано та розглянуто створення пробіотичного лікарського засобу/харчової добавки на основі Lactobacillus reuteri.

\subsection{1. Пробіотики та їх поширення на українському фармацевтичному ринку}

Пробіотики - це бактеріальні препарати з живих мікробних культур, які призначені для корекції нормальної мікрофлори господаря та лікування ряду захворювань. Доведено, що пробіотики приймають участь у процесах утворення вільних амінокислот, органічних кислот, олігосахаридів, коротколанцюгових жирних кислот, біологічно активних пептидів, бактеріоцину, сприяють зниженню рівня холестерину, конкурентно взаємодіють 3 молекулами адгезії для патогенних бактерій, мають імуностимулюючу, антиоксидантну дію, нейтралізують харчові канцерогени, впливають на синтез вітамінів. Крім того, активно вивчається цілий ряд імовірних позитивних ефектів пробіотиків: антиканцерогенний, антидіабетичний, антиалергічний, протизапальний тощо.

Оральні пробіотики повинні відповідати наступним вимогам [340]:

1. Мати цитоадгезивні властивості та колонізуючу здатність. 2. Володіти стійкістю до антибіотиків. 3. Активно пригнічувати ріст патогенних мікроорганізмів. 4. Володіти високою стійкістю до несприятливих умов оточуючого середовища. 5. Мати високу синтетичну активність, зокрема продукувати антимікробні речовини. 6. Бути нешкідливими для макроорганізму та його аутомікрофлори в цілому. 7. Стимулювати (моделювати) специфічні та неспецифічні механізми резистентності макроорганізму. 8. Бути генетично 
стабільними. 9. Важливе значення має походження продуценту пробіотика. 10. Технологічні характеристики продуценту.

Отже, з вище наведеного переліку можна зробити висновок, що не всі види мікроорганізмів можуть відповідати вимогам до цих характеристик. В основному, як пробіотики у фармації та харчовій промисловості використовують представників родів Bifidobacterium (серед них найпоширеніші B. bifidum, B. infantis B. longum, B. breve) та Lactobacillus (серед них найпоширеніші $L$. bulgaricus, L. acidophilus, L. plantarum, L. rhamnosus, L. casei, L. reuteri, L. helveticus).

Для створення максимально ефективного препарату використовують не тільки один штам мікроорганізму, а намагаються їх комбінувати, базуючись на їх трофічних зв'язках та технологічних властивостях.

Згідно літературних даних розрізняють п’ять поколінь пробіотичних препаратів:

I покоління - монокомпонентні препарати, які містять один штам бактерій (біфідобактерії, лактобактерії, колібактерії, аерококі);

II покоління - антагоністи, які самостійно елімінуються організмом i містять спорові бацили та дріжджеподібні грибки;

III покоління - комбіновані препарати, які містять різні штами мікроорганізмів одного або різних видів;

IV покоління - синбіотики - це різновид комбінації пробіотичного i пребіотичного компонентів;

V покоління - рекомбінантні або генно-інженерні пробіотики, які створені на основі генно-інженерних штамів мікроорганізмів, їх метаболітів, структурних компонентів і мають задані характеристики.

На фармацевтичному ринку України представлені покоління пробіотиків у різних лікарських засобах, що наведені у табл. 1 [341, 342]. 
Таблиця 1. Склад та класифікація пробіотиків за поколіннями

\begin{tabular}{|l|l|l|}
\hline $\begin{array}{l}\text { Покоління } \\
\text { пробіотиків }\end{array}$ & \multicolumn{1}{|c|}{ Вид бактерій } & \multicolumn{1}{|c|}{ Назва препарату } \\
\hline I & Біфідобактерії & $\begin{array}{l}\text { Біфідумбактерин, Біфідумбактерин Форте, } \\
\text { Біфікол, Біфіліз, Пробіфор, } \\
\text { Біфіфор }\end{array}$ \\
\cline { 2 - 4 } & Лактобактерії & Лактобактерин, Лактовіт Форте, Лацидофіл \\
\hline II & Колібактерії & Мутафлор \\
\hline III & $\begin{array}{l}\text { Лактобактерії, } \\
\text { Біфілобактерії, } \\
\text { Коки }\end{array}$ & $\begin{array}{l}\text { Лактомун, Лактіале, Лакто, } \\
\text { Лакак, Ацидолак, Лінекс, Лаціум }\end{array}$ \\
\hline V & Бацили & Біоспорин, Субалін, Ентерожерміна \\
\cline { 2 - 4 } & Сахароміцети & Ентерол 250, Нормагут \\
\hline
\end{tabular}

\subsection{2. Мікробіота шлунково-кишкового тракту людини}

Склад мікрофлори кишечника дуже неоднорідний і залежить не тільки від ділянки шлунково-кишкового тракту (ШКТ), а й від статі, віку, харчових звичок людини. Загалом у шлунково-кишковому тракті людини налічується понад 400 видів різних мікроорганізмів, серед яких найпоширенішими родами $\epsilon$ Bifidobacterium, Lactobacillus, Enterococcus, Escherichia. Найважливішими фактом, що впливає на склад мікрофлори є такі фізіологічні та морфологічні особливості ділянок ШКТ:

- в шлунку ріст мікроорганізмів обмежується кислим середовищем завдяки низькому рівню $\mathrm{pH}$ шлункового соку;

- уздовж тонкої кишки концентрація мікроорганізмів поступово збільшується, аж до товстого кишечника, де спостерігається максимальна концентрація мікроорганізмів.

Анаеробні бактерії становлять 95\% всієї мікрофлори кишечника, тоді як аеробні - всього 5\%. Проте, у товстому кишечнику, де еволюційно 
сформувались строго анаеробні умови, спостерігається співвідношення анаеробів до аеробів, як 1000:1 [343].

Людина та ії мікроорганізми - єдина симбіотична система, за рахунок якої людський організм може нормально функціонувати, а мікроорганізми виживати і далі поширюватись у екосистемі. У ШКТ людини мікробіота являє собою тонку біоплівку (рис. 1), яка кріпиться до епітеліоцитів слизових оболонок і відіграє важливу роль у формуванні здоров’я, забезпечуючи:

- імунну функцію (синтез імуноглобулінів, забезпечення функціонування імунних клітин);

- травлення та синтез важливих метаболітів (ферментів, вітамінів);

- «мікробний фільтр», який заважає адгезії на поверхні кишечника патогенних та умовно патогенних мікроорганізмів;

- забезпечує трофічний та енергетичний зв'язок між клітинами слизової оболонки;

- виконує детоксикуючу функцію [344].

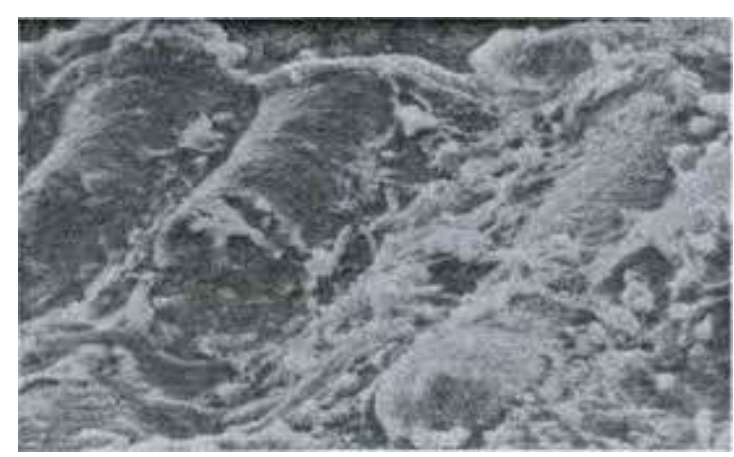

Рисунок 1. Біоплівка епітелію кишечника

Загалом мікробіота ШКТ - це унікальна для кожної людини динамічна система, яка змінюється з часом та адаптується відповідно до потреб та стану організму.

Як вже було зазначено, до основних представників мікробіоти людини належать представники роду Lactobacillus, типовим видом якої є Lactobacillus reuteri. Цей вид має наступні морфологічні та фізіологічні властивості:

- грампозитивні паличкоподібні мікроорганізми, які з часом змінюють свою морфологію до більш зігнутих форм; 
- має здатність до адгезії до муцину епітеліоцитів. Можливий механізм даного процесу пов'язують із властивістю L. reuteri виробляти поверхневі речовини (муцин-зв'язуючі протеїни, D-аланін-LTA, екзополісахариди, глюкозилтрансферазу А, інулінсахарозу), що сприяють адгезії і формуванню активної біоплівки. Дана біоплівка відіграє роль в імунітеті шляхом синтезу реутерину та модуляції цитокінінів, імуностимулюючих факторів та супресуванням виробництва фактора некрозу пухлин (ФНП) [345];

- бактеріям цього роду притаманна антагоністична дія по відношенню до різних родів патогенних мікроорганізмів, зокрема Escherichia, Salmonella, Shigella, Proteus, Pseudomonas, Clostridium i Staphylococcus та, у меншій мірі, вони впливають на роди Streptococcus, Pediococcus, Leuconostoc i Lactobacillus. Бактерії цього роду проявляють фунгіцидну дію на представників родів Candida, Torulopsis, Saccharomyces, Aspergillus, Fusarium та протизойну на паразитичний вид Trypanosoma cruzi [346].

Даний вид був виділений з різних частин ШКТ (тонкого кишечнику, шлунку, товстого кишечника, калу) людини, мишей, свиней, щурів, курей та індичок Герхардом Ройтером наприкінці 1960-х років [347]. Проте, крім травного тракту, L. reuteri були знайдені і в грудному молоці жінок, при чому у різних країнах світу [348].

Як і вся природня мікрофлора, L. reuteri зазнає значного агресивного впливу при використанні антибіотиків. У зв'язку з цим можна спостерігати розлади травлення та збільшення частоти випадків запальних хворіб у пацієнтів, у яких виявлено зниження або відсутність клітин L. reuteri [349].

Як вже зазначалось вище, одним із факторів формування імунної відповіді за допомогою L. reuteri є синтез антибактеріальних речовин, таких як перекис водню, реутерин, реутицелін. Найважливішим 3 точки зору промислового використання $є$ реутерин - це еквімолярна суміш мономерних, гідратованих мономерних і циклічних димерних форм бета-гідроксипропіональдегіду. При 
мікробіологічному синтезі його вихідною речовиною є гліцерин, тому цей синтез можна відтворити у лабораторних умовах, проте за дотриманням умов, які характерні для життя даного виду ( $\mathrm{T}=37^{\circ} \mathrm{C}, \mathrm{pH}=5-7$, анаеробні умови) [350].

Для вирішення проблеми з надмірним використанням антибіотиків все ширше використання у фармації та харчовій промисловості отримують автохтонні для людини види, такі як L. reuteri.

Цей вид проявляє значний терапевтичний ефект на здоров'я людей та тварин, у ШКТ яких він поширений.

Для фармакологічної та ветеринарної галузей $L$. reuteri можна застосовувати для:

- виробництва вітамінів $\mathrm{B}_{12}, \mathrm{~B}_{9}$ та $\alpha$-лізину;

- лікування мієлоїдної лейкемії, хвороби Крона, остеопорозу;

- виробництва пробіотичних лікарських препаратів (штами АТСС 55730, L. reuteri DSM 17938 (торгівельна назва L. reuteri Protectis));

- покращення стану ротової порожнини (зменшення частоти кровотеч 3 ясен, зменшення кількості зубного нальоту), для цього використовуються штами L. reuteri DSM 17938 і L. reuteri ATCC PTA 5289 (торгівельна назва L. reuteri ProDentis );

- попередження виникнення гастриту шляхом зв'язування Helicobacter pylori за допомогою синтезу сульфід-зв'язуючого білка;

- лікування коліків у немовлят при використанні дитячого харчування 3 додаванням штаму L. reuteri 17938 [351];

- використання штаму L. reuteri АТCC РТА 6475 для попередження розвитку остеопорозу, викликаного нестачею естрогену в період менопаузи;

- використання штаму L. reuteri NCIMB 30242, як добавку у кисломолочні продукти для зниження рівня холестерину у крові людей;

- використання штаму L. reuteri 15007 (торгівельна назва L. reuteri fermentum) у кількості $6 \times 10^{9} \mathrm{KУО/день} \mathrm{у} \mathrm{кормах} \mathrm{для} \mathrm{поросят} \mathrm{для}$ покращення стану здоров’я тварин після відлучення від матері [352]. 
Отже, зважаючи на такий значний вплив на організм людини і тварин існує серйозна необхідність впровадження цього виду у промислове застосування для покращення загального стану здоров'я.

\subsection{3. Вивчення морфологічних і окремих фізіологічних властивостей}

\section{Lactobacillus reuteri}

Для отримання та подальшого вивчення Lactobacillus reuteri ми отримували нагромаджувальну культуру шляхом ресуспендування аліквоти дитячого харчування «Nestogen 4» у фізіологічному розчині та посіву суспензії на поживне середовище сусла-агар $\left(6^{0}\right.$ Б). Шляхом проведення ряду пасажей на сусло-агарі (CA) $32 \% \quad \mathrm{CaCO}_{3}$ отримали чисту культуру, яка за морфологічними характеристиками колоній, будовою клітин та їх тинкторіальними властивостями відповідала виду L. reuteri.

Клітини виділеного штаму, а також інших представників родини Lactobacteriaceae фарбували фуксином або за Грамом згідно стандартних методик і розглядали в світлопольний мікроскоп «Біолам» при збільшенні $15 \times 90$.

В якості середовищ для культивування використовували молоко «Селянське ультрапастеризоване» (3,2 \% жирності) та «Mlekovita» (безлактозне молоко 3,2 \% жирності, виробник Польща). Вибір останнього субстрату був обумовлений зацікавленістю про можливість створення пробіотичного продукту для тієї категорії населення, яка має алергічну реакцію на лактозу.

Титровану кислотність молока та отриманих продуктів проводили стандартним методом титрування 3 0,1 н $\mathrm{NaOH}$. Лактозу визначали йодометричним методом. Антибіотикограму проводили зі стандартними дисками диско-дифузійним методом згідно рекомендацій [353].

На етапі виділення нагромаджувальної культури 3 дитячого харчування «Nestogen 4» шляхом послідовного пересівання на чашки Петрі отримано бежеві колонії з ризоїдними краями, складчастої форми, зверху злегка підняті, шкірястої структури (рис. 2). 


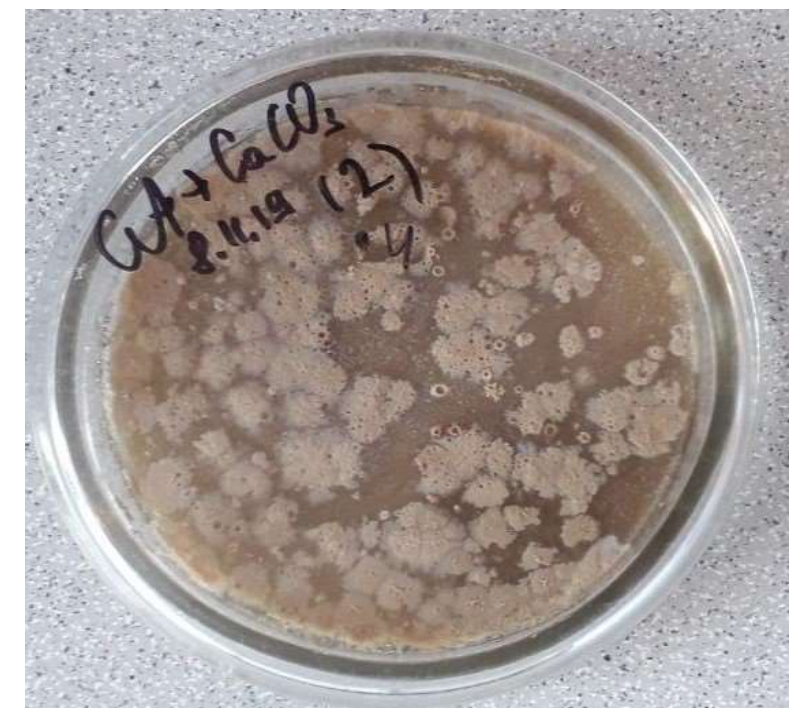

Рисунок 2. Колонії виду L. reuteri на середовищі СА з додаванням 2\%

$\mathrm{CaCO}_{3}$ після 48 годин культивування

На етапі визначення чистоти отриманої культури проводили мікроскопування у порівнянні $з$ попередньо вирощеною на СА культурою препарату «Linex», у якому містяться L. acidophilus (ssp. L. gasseri) та Enterococcus faecium (рис. 3, 4).

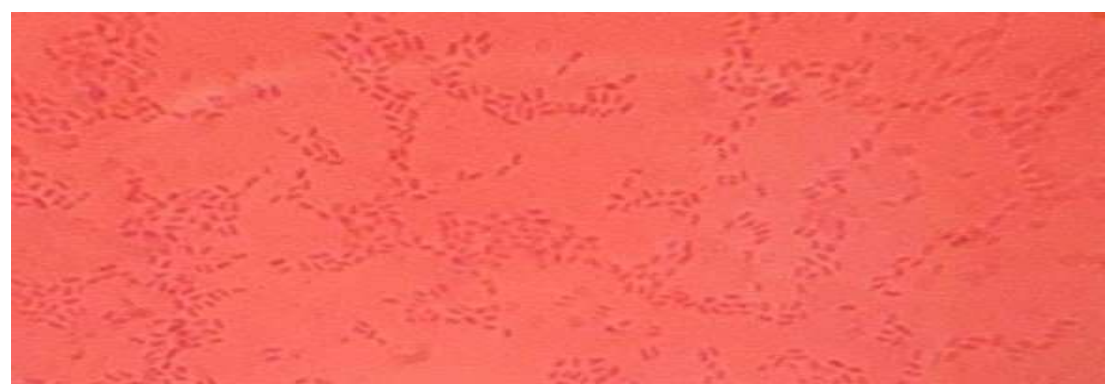

Рисунок 3. Морфологія бактерій L. reuteri $(15 \times 90)$

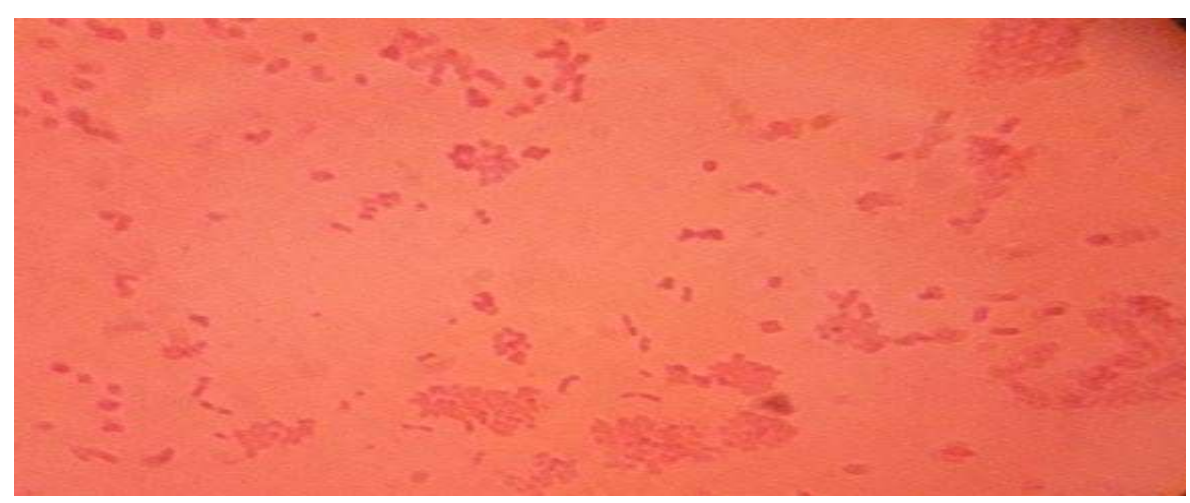

Рисунок 4. Морфологія бактерій препарату «Лінекс» (15x90)

У результаті мікроскопування препарату «Лінекс» були знайдені клітини короткої товстої паличкоподібної форми та диполококи, що є очікувано для 
даного препарату. У виділеній культурі L. reuteri були знайдені тільки короткі товсті паличкоподібні клітини, що повністю відповідає літературним даним.

Згідно літературних даних L. reuteri фарбуються за Грамом позитивно, що і було підтверджено експериментально (рис. 5).

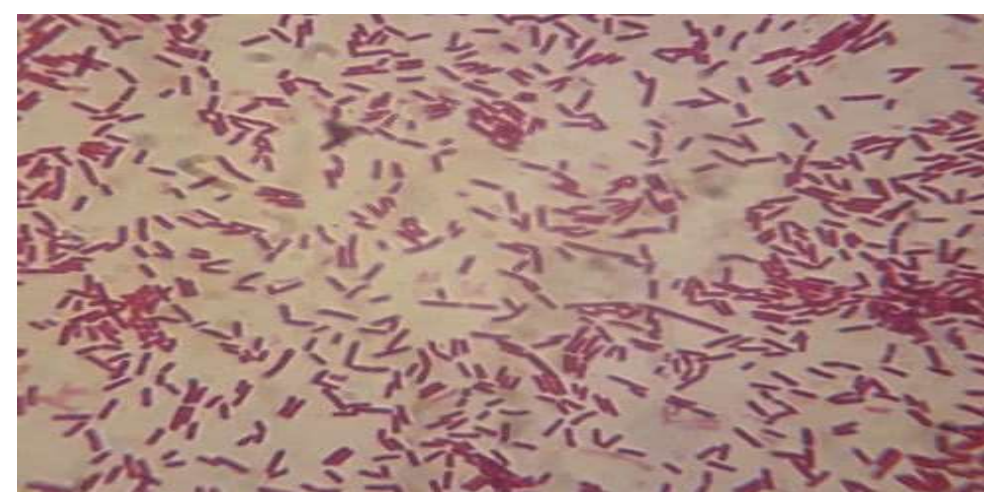

Рисунок 5. Фарбування за Грамом добової культури досліджуваного виду $(15 \times 90)$

У результаті морфологічного аналізу можна стверджувати, що отримана культура мікроорганізмів належить до виду L. reuteri.

Всі молочнокислі бактерії мають здатність зброджувати молоко з різною ефективністю. Наприклад, існують такі активні кислотоутворювальні бактерії як L. bulgaricus, L. acidophilus, які мають широке використання у харчових технологіях для виробництва кисломолочних продуктів.

Для перевірки зброджувальної здатності отриманої культури проводилась серія експериментів, в яких в якості субстрату використовувалось молоко «Селянське ультрапастеризоване» $(3,2 \%$ жирності). Згідно попередніх досліджень [354] в якості контролю обрали йогурт «Галичина».

У результаті проведених дослідів можна побачити, що зброджувальна активність проявляється лише на другу добу ферментації, що свідчить про те, що вид L. reuteri є слабким кислотоутворювачем. В усіх повторностях кінцева кислотність через 48 год. культивування становила 92-102 ${ }^{0}$ Т. В результаті ферментації контрольного взірця утворювався молочнокислий напій кислотністю $132-138^{0} \mathrm{~T}$ (рис.6). 


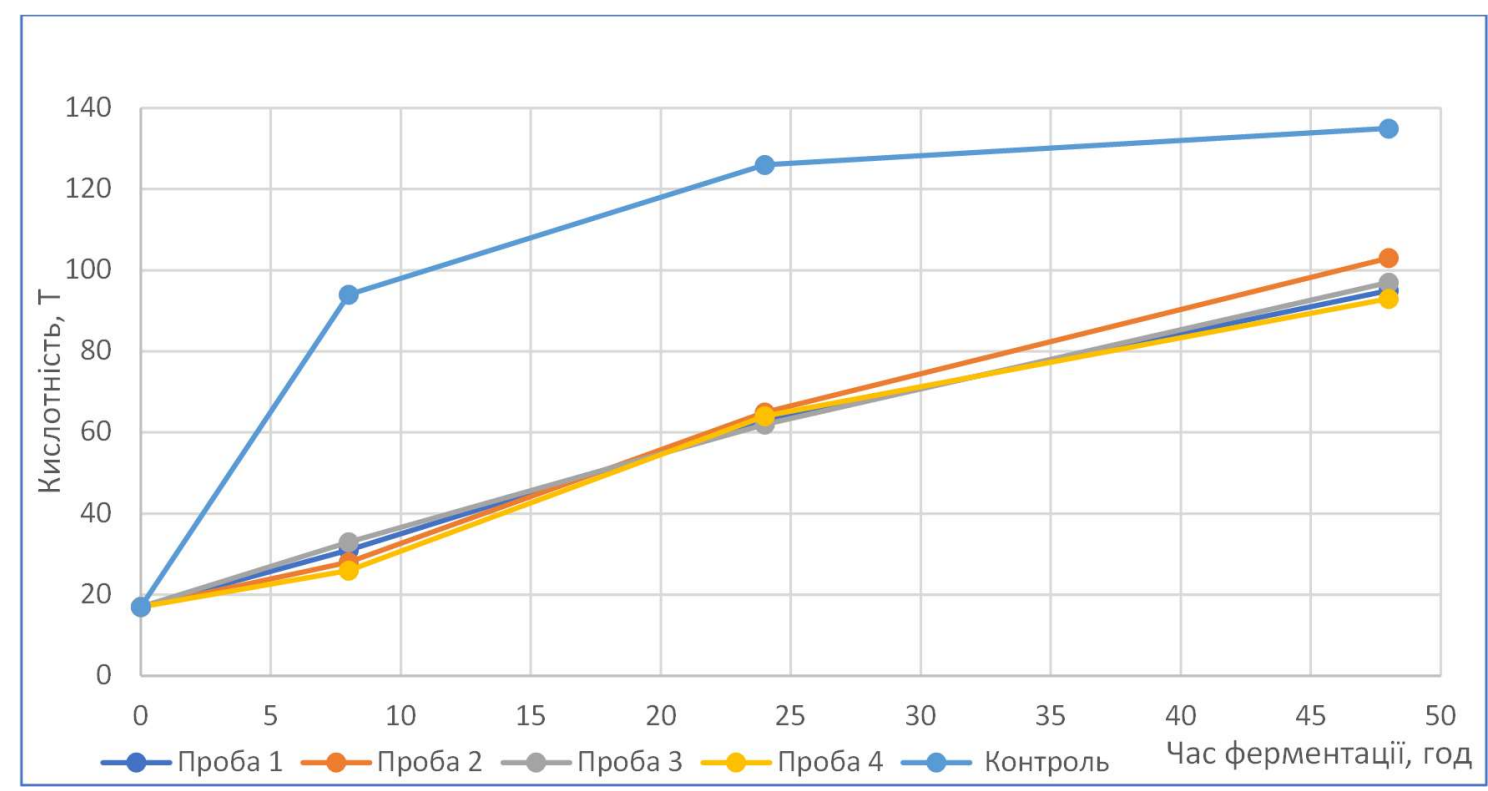

Рисунок 6. Визначення ферментативної активності досліджувальної культури на стандартизованому промисловому молоці.

Ферментація безлактозного молока «Mlekovita» досліджуваною культурою проводилась згідно попередньої методики. Результати отриманих експериментів свідчать про те, що ферментація відбувалася ще повільніше, ймовірно через низький вміст лактози у середовищі (рис.7).

Відповідно до отриманих результатів доцільність виробництва монокультуральних кисломолочних продуктів на основі L. reuteri $€$ низькою 3 точки зору споживчих властивостей.

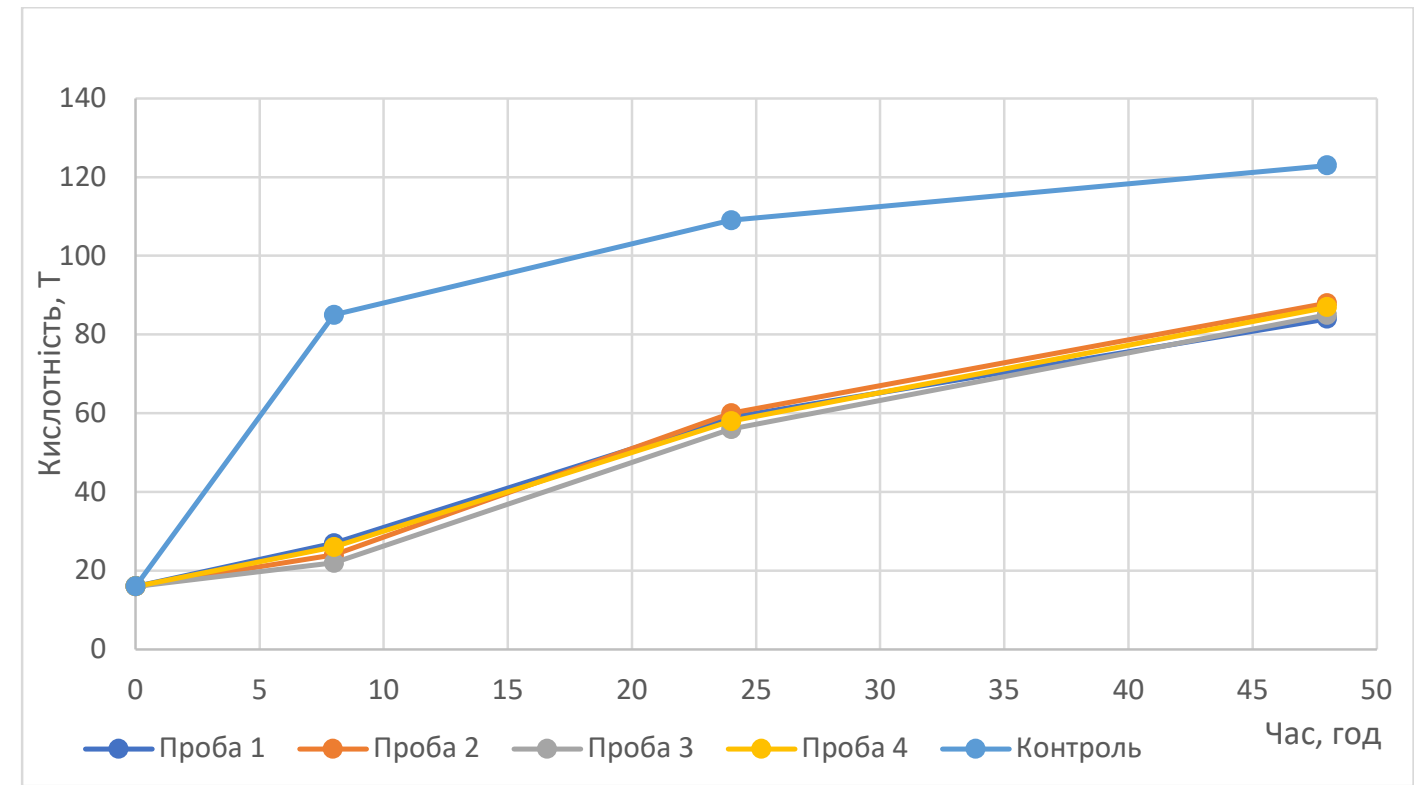

Рисунок 7. Визначення ферментативної активності досліджувальної культури на безлактозному молоці. 
Оскільки, згідно вимог, пробіотичні мікроорганізми мають проявляти певну стійкість до антибіотичних препаратів, тому було проведено визначення резистентністі до таких антибіотиків як: ванкоміцин, стрептоміцин, ристоміцин, левоміцетин, лінкоміцин (табл.2).

Таблиця 2. Чутливість мікроорганізмів до антибіотиків

\begin{tabular}{|l|l|l|}
\hline Антибіотик & Зони затримки росту, см & Чутливість \\
\hline Ванкоміцин & $2 \pm 0,1$ & Мало-чутливі \\
\hline Стрептоміцин & $2 \pm 0,1$ & Мало-чутливі \\
\hline Ристоміцин & $1,5 \pm 0,05$ & Мало-чутливі \\
\hline Левоміцетин & $1,4 \pm 0,05$ & Мало-чутливі \\
\hline Лінкоміцин & $2,5 \pm 0,1$ & Помірно чутливі \\
\hline
\end{tabular}

Як видно з отриманих результатів вид L. reuteri $є$ достатньо безпечним для використання у фармацевтичній промисловості. Помірна чутливість до різноманітних антибіотиків свідчить на користь ймовірності використання цього виду для виробництва пробіотичних добавок.

На основі літературних та отриманих експериментальних даних можна розглянути доцільність виробництва лікарського засобу на основі L. reuteri. У зв'язку з безсумнівною користю застосування цих бактерій, виникла пропозиція використовувати суспензію цих бактерій у такій лікарській формі як «саше».

Нами запропонована наступна схема виробництва лікарського засобу/харчової добавки у формі «саше»:

1. Перед безпосереднім виробництвом лікарського засобу відбувається підготовка поживного середовища та його стерилізація, а також нарощування живої культури.

2. І стадія - приріст біомаси, коли поживне середовище та жива культура знаходяться в оптимальних умовах у реакторі.

3. II стадія - фільтрування на якій відбувається відділення культивованих мікроорганізмів від поживного середовища.

4. III стадія - утворення суспензії, якому передує приготування стерильного розчину сахарози.

5. Пакетування. 
Виходячи з аналізу літературних даних та власних експериментів можна зробити висновки, що в наш час існує серйозна загроза для людського здоров'я від надмірного використання антибіотиків, що може проявлятись у різноманітних функціональних порушеннях шлунково-кишкового тракту, таких як дисбактеріоз та порушеннях імунітету. Для захисту організму людини треба намагатись використовувати максимально автохтонні види мікроорганізмів та вводити їх у харчові продукти та лікарські засоби, біологічно-активні добавки. Вид L. reutter на сьогоднішній день отримує все більше розповсюдження на ринку пробіотичних добавок через свій широкий спектр біологічної дії. Було виділено та досліджено морфологічні та окремі фізіологічні властивості виду $L$. reuteri у лабораторних умовах. При досліджуванні зброджувальної активності $L$. reuteri було доведено, що цей вид є слабким кислотоутворювачем і не підходить для створення монокультуральних кисломолочних продуктів. Пропонується виробництво монокультурального лікарського засобу у формі «саше» на основі L. reuteri. 